\title{
Improvement of the seismic retrofit performance of damaged reinforcement concrete piers using a fiber steel composite plate
}

\author{
K.-B. Han, P.-Y. Song, H.-S. Yang, J.-H. Lee, J.-M. Kang \\ \& H.-J. Kim \\ Super Long Span Bridge R\&D Centre, Korea Expressway Corporation, \\ Republic of Korea
}

\begin{abstract}
An experimental study was conducted to verify the application and efficiency of the jacket retrofit method to ensure seismic performance of damaged reinforcement concrete (RC) bridge piers. A total of $4 \mathrm{RC}$ bridge piers were made and then 3 piers were pre-loaded under the range of service load to be damaged. These piers were retrofitted and repaired using a carbon fiber reinforced polymer (CFRP), steel plate, and fiber steel composite (FSC) plates. These retrofitted and repaired piers were subjected to repeated monotonic loading. Hysteresis and ultimate behaviours of the $3 \mathrm{RC}$ piers were evaluated and compared with those of 1 non-damaged pier (standard specimen). As a test result, the retrofitted and repaired $\mathrm{RC}$ bridge piers applied by the jacket retrofit method were ensured under the targeted displacement ductility and ultimate load. The ultimate load and displacement ductility of the pier retrofitted and repaired by FSC plate were higher than those of other piers by CFRP and steel plates and also the pier by FSC plate showed better energy dissipation capacity than others. Generally, RC bridge pier retrofitted and repaired with the jacket retrofit method has low ductility but it was found that the pier retrofitted and repaired by FSC plate combined with CFRP and steel wire had overcome effectively this disadvantage through ductility evaluation based on the concept of energy numerically. This experiment showed that one could improve the safety margin and targeted ductility by repairing the cracks, spalls, etc. of the damaged RC
\end{abstract}


bridge piers appropriately and then retrofitting them with the high ductile materials.

Keywords: seismic performance, damaged RC piers, FRP plate, steel plate, FSC plate, ductility, concept of energy.

\section{Introduction}

An earthquake can make the member of the bridge damaged. In case of large damage, it can lead the collapse of the bridge. The bridge that can be damaged during earthquakes should be secured of required seismic performance. First, proper seismic performance evaluation should be executed In order to ensure seismic performance. If serious damage is expected as a result of evaluation, it is required to retrofit the bridge. Currently, a wide variety of methods has been proposed for a seismic retrofit [1-4]. The study on the one of these seismic retrofit methods repairing and retrofitting damaged major members such as concrete slabs and girders by using composite materials such as fiber reinforced polymer (FRP) and steel plate has been extensively done [5-8]. For reinforcement concrete (RC) piers in particular, the simple and effective method retrofitting the RC piers by covering with the steel plate or FRP externally has been suggested. The retrofit of RC piers with steel plate was first proposed by Sun et al. [9], since then; study on this method has been continuously undertaken by Preistley et al. [10]. In addition, the study on applying FRP plate instead of steel plate to increase ductility and strength of piers has been done by Matsuda et al. [11], Xiao et al. [12], etc.

However, there is a disadvantage that brittle failure of the structure occurs if the damaged structural members are retrofitted by the FRP jacket generally because retrofit FRP material is brittle and interface failure occurs at the bonding surface. In recent years, in order to enhance these shortcomings, fiber-steel (FS) plate combined with FRP and steel wires has been developed.

Thus, in this paper, the application and efficiency of jacket retrofit method were experimentally verified to obtain seismic performance of the damaged RC piers. This study was carried out by following steps. (1) A total of $4 \mathrm{RC}$ piers with same reinforcement ratio were made. (2) The behaviour of one RC pier (standard specimen) was evaluated under the repeated monotonic increasing loading, a quasi-static test. (3) The other $3 \mathrm{RC}$ bridge priers were pre-loaded under the initial yielding force measured by the quasi-static test of the standard specimen to be damaged. (4) The cracks of 3 damaged piers were repaired by injecting epoxy and then were retrofitted by using FSC plate, CFRP, and steel plate. (5) The hysteretic behaviour of each repaired and retrofitted specimen under the cyclic loading was evaluated respectively. (6) Maximum force and maximum displacement of 3 piers were compared with those of a standard specimen. 


\section{Experimental program}

\subsection{Specimen production}

A total of $4 \mathrm{RC}$ piers were made in order to compare seismic retrofit performance experimentally. Standard specimen, specimen retrofitted by CFRP, specimen retrofitted by FSC plate, and specimen retrofitted by steel plate were made and the behaviours of each specimen were evaluated respectively.

In order to compare performance between standard specimen and retrofit specimens, the detail arrangement of reinforcement and section of the specimens were made identically. Though specimens were circular in cross section, foundation and coping of the specimens had different cross sections because the foundation should have greater stiffness than the pier to be fully fixed and the section of the coping should be determined by considering shape and size of the actuator. The 28 days concrete compressive strength $\left(f_{28}\right)$ was in the $24 \mathrm{MPa}$. Pouring the concrete into the specimens was done at the foundation first and then done at the pier. Strain gauges were attached to the main and stirrup reinforcement to measure the strain of reinforcement before pouring concrete. Main reinforcement was D22 (diameter of $22 \mathrm{~mm}$ ), hoop reinforcement and cross-tie were $D 13$ (diameter of $13 \mathrm{~mm}$ ). As using that reinforcement, the problems about geometric and material similarities that might arise because of a small-scale model was excluded as much as possible. The cross section of specimen is shown in Figure 1 and the making of the specimens is shown in Figure 2.

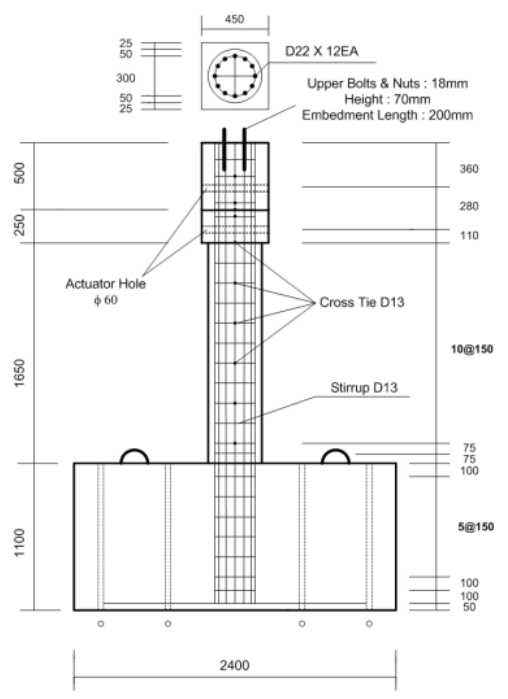

Figure 1: Cross section of specimen (unit: $\mathrm{mm}$ ).

Except for the standard specimen, the other $3 \mathrm{RC}$ bridge priers were preloaded under the initial yielding force measured by the quasi-static test of the standard specimen to be damaged in advance and then were retrofitted by using 


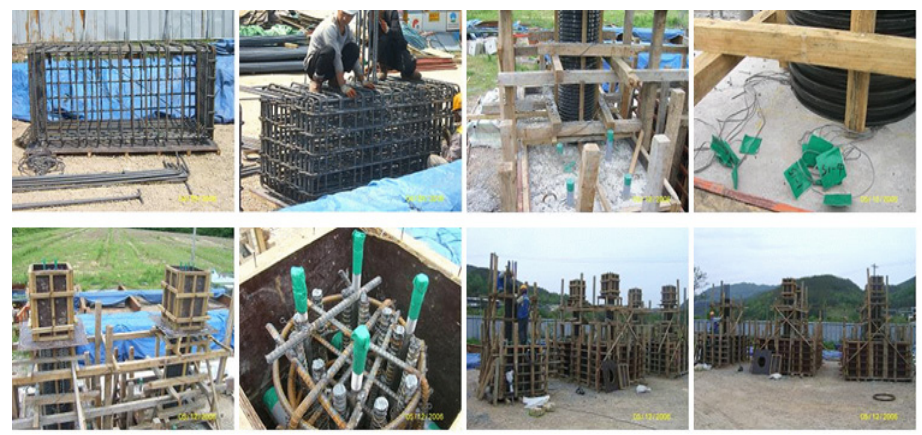

Figure 2: $\quad$ The making of specimens.

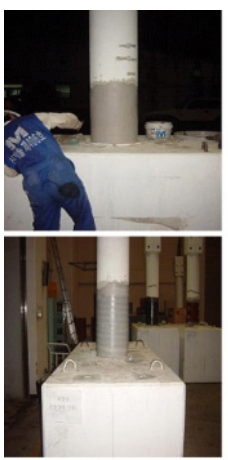

(a)

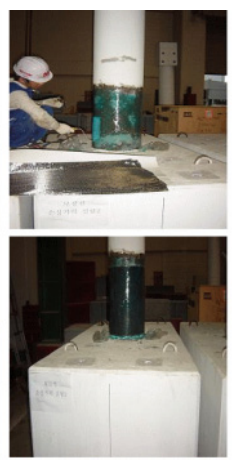

(b)

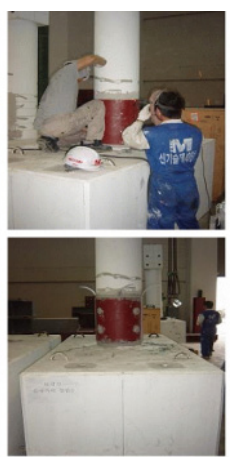

(c)

Figure 3: $\quad$ Repair/retrofit of the damaged specimen by pre-loading. (a) FSC plate retrofit; (b) CFRP retrofit and (c) steel plate retrofit.

FSC plate, CFRP, and steel plate after repair of crack by injecting epoxy. The amount of retrofit for each method was determined to make the same strength. The process of repair/retrofit is shown in Figure 3.

\subsection{The process of test and measurement detail}

By using an actuator with built in a load cell and a displacement cell, loads and displacement of the specimens were measured. Flexural failure was expectedbecause the aspect ratio was 4.13 as $1650 \mathrm{~mm}$ in the height and $400 \mathrm{~mm}$ in the diameter of the pier. Thus, plastic hinge could be occurred mostly at the bottom of the pier, so strain gauges were attached to the bottom of the pier. For the quasi-static test, the axial force corresponding to $0.15 \times f_{28} \times$ concrete section $\left(A_{g}\right)$ was constantly loaded using an oil jack. And the lateral force was loaded as a displacement control method using hydraulic actuator with capacity of $500 \mathrm{kN}$. The lateral load was loaded repeatedly as 3 cycles up to the yield displacement $\left(\Delta_{y}\right)$ obtained from the experiment. Installation locations of the gauges and a range of loading for quasi-static test are shown in Figure 4. 

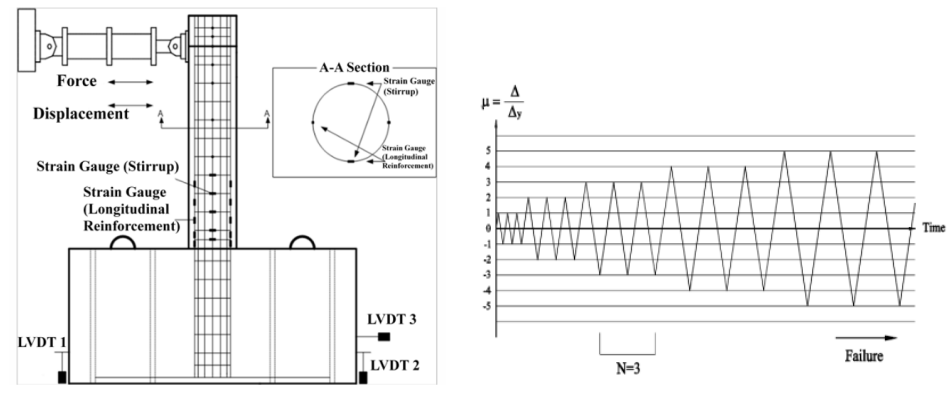

Figure 4: $\quad$ Measurement detail and loading range for quasi-static test.

\section{Test results}

As a test result, an initial crack of the standard specimen occurred horizontally at the interface between a foundation and a pier. And as the load was gradually increased, the horizontal and vertical cracks occurred at the middle of the pier. Finally, as typical flexural failure such as a separation of the concrete cover and crushing was shown, load-carrying capacity was drastically reduced.

In the case of repaired and retrofitted specimens, the initial cracks occurred horizontally above the boundary of the retrofit plates. As the load was gradually increased, the horizontal and vertical cracks were occurred at the middle of the piers. However, the numbers of vertical cracks were significantly less than those of the standard specimen due to the retrofit effect. As the load was increased, the reinforcement was yielded and showed ductility and then failures were finally shown as a debonding of the retrofit plates. Load-displacement curves for each specimen are shown in Figure 5.

Retrofit efficiency was evaluated and compared between the standard specimen and repaired and retrofitted specimens by the retrofit method as shown in Figure 6. The retrofit specimens have relatively higher strength and ductility than the standard specimen. The specimen with FSC plate retrofit has greater retrofit effect than the others relatively. Despite the advantages of retrofit material, the specimens with FRP and steel plate have lower retrofit efficiency because of defects that occur during construction or curing of concrete and bonding performance degradation.

\section{Ductility evaluation using the concept of energy}

Ductility of reinforced concrete beams and piers retrofitted by the jacket retrofit method is generally reduced by brittle failure pattern such as the brittle nature of retrofit material and early debonding at the bonding surface, etc. However, it is insufficient to judge whether the structure has the required ductile capacity with only simple comparison of the displacement-ductility. Thus, this paper evaluated the ductility of each specimen based on the concept of energy. Ductility based on the concept of energy is defined as the ratio of any two of inelastic, elastic, and 


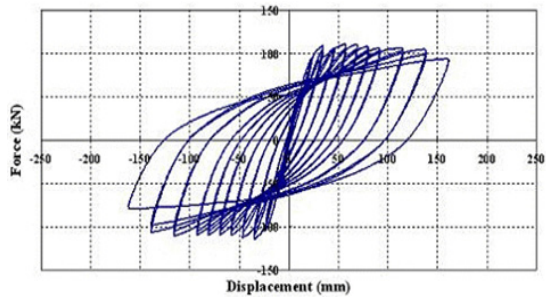

(a)

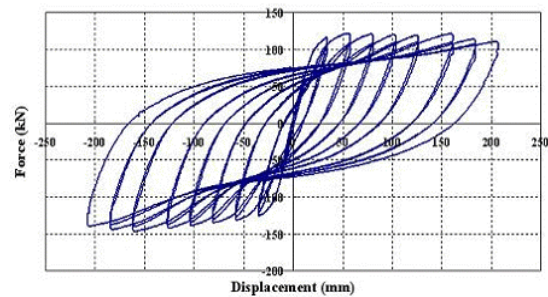

(c)

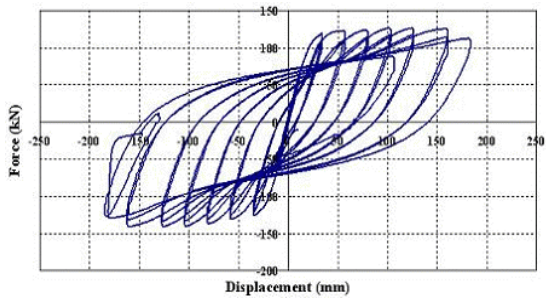

(b)

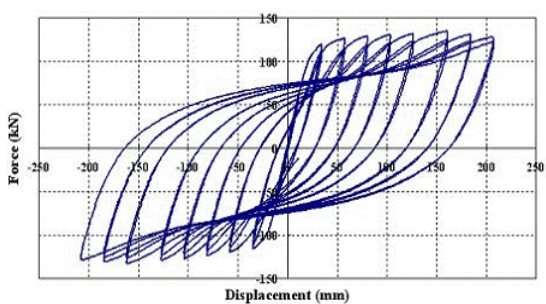

(d)

Figure 5: The load-displacement hysteresis curve. (a) Standard specimen; (b) retrofit specimen with steel plate; (c) retrofit specimen with FSC plate and (d) retrofit specimen with CFRP.

total energies. In using the energy ratio, however, it is not easy to determine elastic energy and inelastic energy. In this paper, the method of finding a point where the load was changed differently in the load-deflection curve was selected and the inflection point of energy was determined. The method of calculating the energy ductility indices is shown in Figure 7.

The slopes, $S_{1}, S_{2}$, and $S_{3}$ were calculated by numerical integration and the loads, $\mathrm{P}_{1}$ and $\mathrm{P}_{2}$ were the points where other extended slope are met and $\mathrm{P}_{3}$ was ultimate load. The elastic and inelastic energies can be calculated using Equation (1) and the energy ratio of inelastic energy and total energy can be calculated using Equation (2).

$$
S=\frac{P_{1} S_{1}+\left(P_{2}-P_{1}\right) S_{2}+\left(P_{3}-P_{2}\right) S_{3}}{P_{3}}
$$

where S, S1, S2, S3 : slopes, P1, P2, P3 : loads

$$
\mathrm{ER}=\frac{\text { Inelastic Energy }\left(\mathrm{E}_{\mathrm{i}}\right)}{\text { Total Energy }\left(\mathrm{E}_{\mathrm{t}}\right)}
$$


Pier Test - Force : Displacement

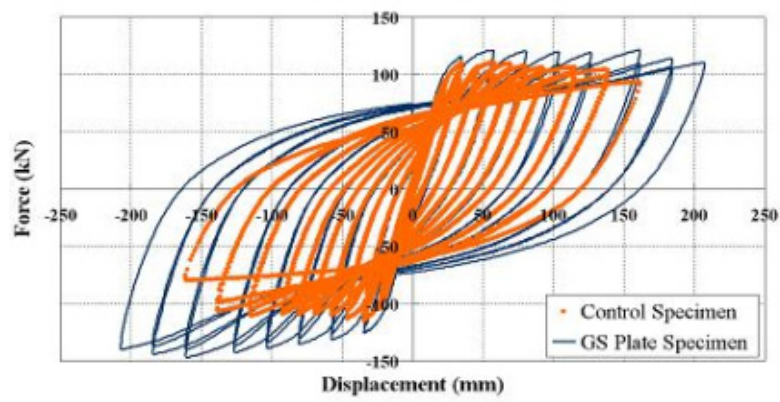

(a)

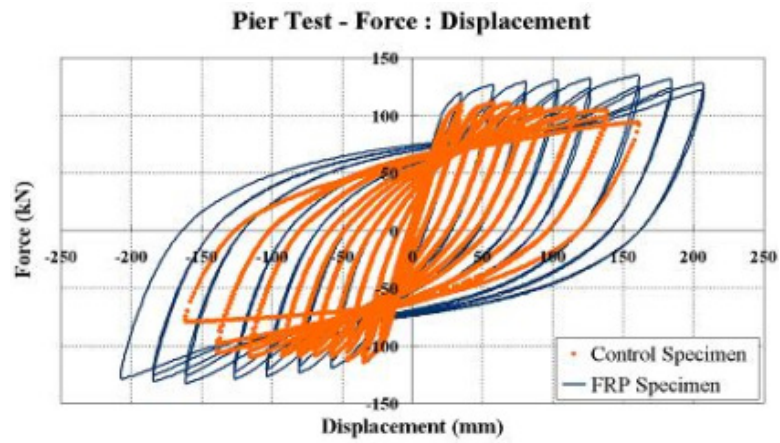

(b)

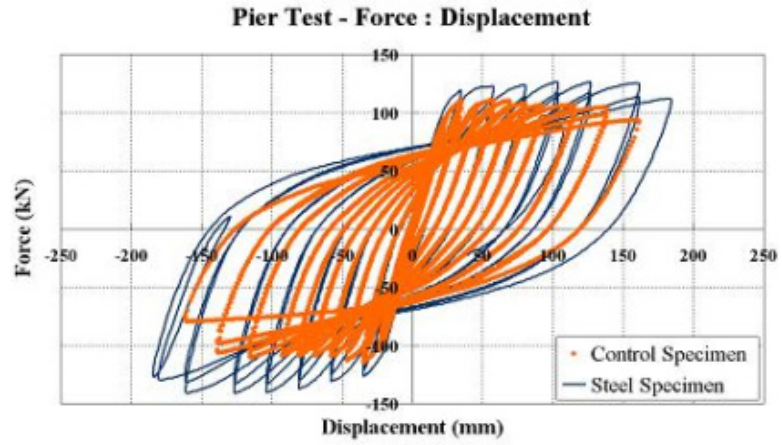

(c)

Figure 6: Comparison curves between the standard specimen and retrofit specimens. (a) standard-FSC plate retrofit; (b) standard-CFRP retrofit and (c) standard-steel plate retrofit. 


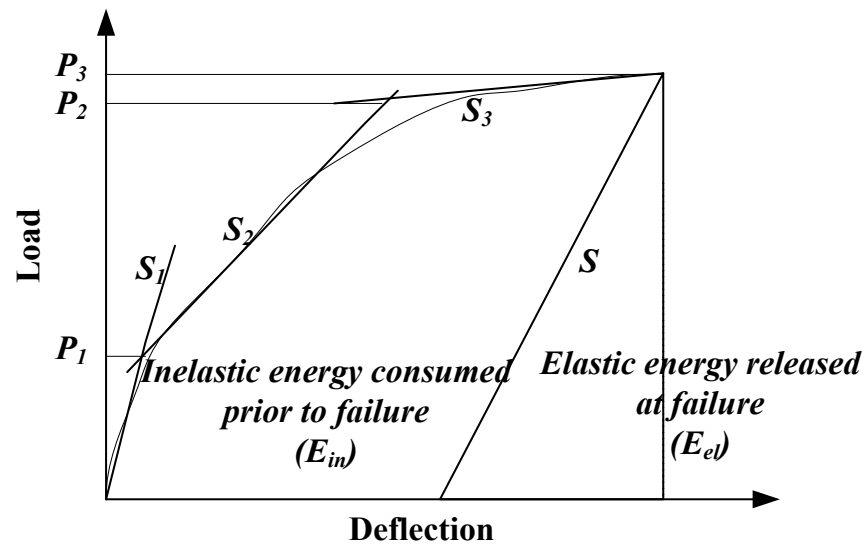

Figure 7: Total, elastic, and inelastic energies.

According to the study results by Grace et al. [13], ductile failure is dominant when the energy ratio is greater than $75 \%$, and semi-ductile is considered when the energy ratio is in range of $70-74 \%$. If the energy ratio is less than $69 \%$, brittle failure is dominant.

The ductility of specimens can be classified according to the energy ratio shown in Table 1. The failure type of the retrofit specimens was classified as ductile failure in this test. It is restrictively found that the retrofit structure with the jacket retrofit method secures ductility. It is considered that ductility is increased by the improvement of confinement effect of RC piers because retrofit materials are bonded to the outside of the piers as the type of jackets and material resistance is enough against tensile force under ultimate behaviours.

Table 1: Ductility evaluation using the concept of energy.

\begin{tabular}{|c|c|c|c|c|c|c|}
\hline \multirow[b]{2}{*}{ Specimen } & \multicolumn{2}{|c|}{ Yield Load } & \multicolumn{2}{|c|}{ Ultimate Load } & \multirow{2}{*}{$\begin{array}{c}\text { Energy } \\
\text { Ratio } \\
\left(E_{i} / E_{t}\right)\end{array}$} & \multirow[b]{2}{*}{ Ductility } \\
\hline & $\begin{array}{l}\text { Load } \\
(\mathrm{kN})\end{array}$ & $\begin{array}{l}\text { Displacement } \\
(\mathrm{mm})\end{array}$ & $\begin{array}{l}\text { Load } \\
(\mathrm{kN})\end{array}$ & $\begin{array}{l}\text { Displacement } \\
(\mathrm{mm})\end{array}$ & & \\
\hline Standard & 65.77 & 13.72 & 110.27 & 51.21 & $76 \%$ & Ductile \\
\hline Steel Plate & 73.23 & 13.85 & 125.17 & 98.72 & $87 \%$ & Ductile \\
\hline CFRP & 74.92 & 13.97 & 120.46 & 105.23 & $88 \%$ & Ductile \\
\hline FSC Plate & 75.06 & 14.09 & 134.38 & 150.17 & $92 \%$ & Ductile \\
\hline
\end{tabular}




\section{Conclusion}

The seismic repair/retrofit performance of jacket retrofit method for damaged RC piers was evaluated and compared experimentally. This study concluded that all specimens repaired and retrofitted by the jacket retrofit method secured targeted displacement ductility and ultimate load. Maximum load and displacement of the specimen retrofitted by FSC plate are higher than those by CFRP and steel plate and it showed better dissipation capacity of energy. Although there is a disadvantage of less ductile on the specimen retrofitted by the jacket retrofit method, it was found that this disadvantage could be overcome effectively in FSC Plate combined with FRP and steel wire. This was verified numerically by ductility evaluation using the concept of energy.

As a result, it was experimentally found that if the damaged $\mathrm{RC}$ piers were repaired properly and then retrofitted by materials with high ductile capacity, they could secure safety margin and targeted ductility prior to be damaged. However, there were local failures due to defects that occur during construction or curing of concrete and bonding performance degradation. This could cause unexpected failure, and the system and plan should be considered in order to prevent local failures.

\section{Acknowledgements}

This study was supported by "Super Long-Span Bridge R\&D Center (08 Construction Technology Innovation Program E01)" funded by the Ministry of Land, Transport, and Maritime Affairs, Korea. The authors gratefully acknowledge this support.

\section{References}

[1] Roberts T. M. and Haji-Kazemi H. A., 1989. Theoretical Study of the Behavior of Reinforced Concrete Beams Strengthened by Epoxy-Bonded Steel Plates", Proceedings of the Institution of Civil Engineers, V. 87, No. 2, pp.39-55.

[2] Zirzba Y. N., Baluch M. H., Basunbul I. A., Sharif A. M., Azad A. K., and Al-Sulaimani, G. J. 1994. Guidelines toward the Design of Reinforced Concrete Beams with External Plates, ACI Structural Journal, V. 91, No. 6, .11-12, pp.639-646.

[3] Christopher K. Y. 2001. "Delamination Failure in Beams Retrofitted with a Bonded Plate", Journal of Materials in Civil Engineering, V. 13, No. 2, pp.106-113.

[4] Han K. B., Park, J. M. and Park. S. K., 2008. "Full-scale pseudodynamic test for bridge retrofitted with seismic isolations", The Baltic Journal of Road and Bridge Engineering, 3(1), 38-46.

[5] Houssam A. Toutanji and Mohamed Saafi, 2000. "Flexural Behavior of Concrete Beams Reinforced with Glass Fiber-Reinforced Polymer (GFRP) Bars", ACI Structural Journal, V.97, No.5, pp.712-719. 
[6] Mahmoud T. EI-Mihilmy and Joseph W. Tedesco, 2000. "Analysis of Reinforced Concrete Beams Strengthened with FRP Laminates", ASCE, V.126 No. 6, pp.684-691.

[7] Bonacci J. F. and Maalej M., 2001. "Behavioral Trends of RC Beams Strengthened with Externally Bonded FRP", Journal of Composites for Construction, pp.102-113.

[8] Christos G. P., Michael F. P. and Kent A. H., 2001. "Fatigue Behavior of RC Beams Strengthened with GFRP Sheets", Journal of Composite for Construction, pp.246-253.

[9] Sun Z., Seible F. and Priestley, M.J.N., 1993. Flexural retrofit of rectangular reinforced concrete bridge column by steel jacking, Structural Systems Research Project, Report SSRP-93/07, University of California, San Diego, pp.215.

[10] Priestley, M,J.N., Seible F., Xiao Y. and Verma, R., 1994. "Steel Jacket Retrofitting of Reinforced Concrete Bridge Columns for Enhanced Shear Strength - Part 1: Theoretical Considerations and Test Design", ACI Structural Journal, Vol. 91, No. 4, pp.394-405.

[11] Matsuda T., Fujiwara H. and Higashida N., 1990. "Effect of carbon fiber reinforcement as a strengthening measure for reinforced concrete bridge piers", Proceedings of 1st US-Japan Workshop on Seismic Retrofit of Bridges, Public Works Institute, Ministry of Construction, Tsukuba, Japan, pp.356-374.

[12] Xiao, Y., Wu, H. and Martin, G.R., 1999. "Prefabricate Composite Jacking of RC Columns for Enhanced Shear Strength", Journal of Structural Engineering, ASCE, Vol. 125, No. 3, pp.225-264.

[13] Grace N. F., Soliman A. K., Abdel-Sayed G., and Saleh K. R., 1998. "Behavior and Ductility of Simple AND Continuous FRP Reinforced Beams", Journal of Composites for Construction, Vol. 2, No. 4, pp.186194. 